\title{
PHYLOGENETIC POSITION OF THE GENUS CHAETONIPHARGUS KARAMAN ET SKET (CRUSTACEA: AMPHIPODA: NIPHARGIDAE) FROM DINARIC KARST. AN EXTREME CASE OF HOMOPLASY.
}

\author{
FILOGENETSKI POLOŽAJ RODU CHAETONIPHARGUS \\ KARAMAN ET SKET (CRUSTACEA: AMPHIPODA: NIPHARGIDAE) \\ IZ DINARSKEGA KRASA. SKRAJNI PRIMER HOMOPLAZIJE.
}

\author{
Boris $\mathrm{SKET}^{1}$ \& Gordan S. KARAMAN ${ }^{2}$
}

http://dx.doi.org/10.3986/fbg0046

\begin{abstract}
Phylogenetic position of the genus Chaetoniphargus Karaman et Sket (Crustacea: Amphipoda: Niphargidae) from dinaric karst. An extreme case of homoplasy.

An alternative, phylogenetically grounded taxonomy of the recently described Chaetoniphargus lubuskensis Karaman \& Sket (Crustacea: Amphipoda: Niphargidae) is presented. The recently described new genus and species, Chaetoniphargus lubuskensis from Dinaric Karst, has formerly only been taxonomically evaluated by a classical approach, based on morphology. Species of genera Niphargobatoides, Niphargobates, Chaetoniphargus, differ from Niphargus spp. mainly by slightly elevated number of maxilla I spines, by gradual reduction of maxillary and mandibular palps, by a strong reduction of urosomal structures. Molecularly, they appear to be nested within the Niphargus tree, but separately. Their collective separation from Niphargus would make the genus Niphargus paraphyletic, but for the low number of these species practically without diminishing the confusing diversity of it. A molecular phylogenetic analysis would include all here studied niphargid species as belonging to Niphargus. The gradual change in morphology of mentioned niphargids produces a smooth transition between Niphargidae and unrelated Metacrangonyctidae. Since other facts speak against the relatedness of both families, this is an additional case of convergence, demonstrating the need of molecular analyses when we speculate on phylogenetic relations within Amphipoda.

Key words: subterranean, taxonomy, phylogeny, Amphipoda, Niphargidae, Metacrangonyctidae, Chaetoniphargus.
\end{abstract}

\section{IZVLEČEK}

Filogenetski položaj rodu Chaetoniphargus Karaman et Sket (Crustacea: Amphipoda: Niphargidae) iz dinarskega krasa. Skrajni primer homoplazije.

Podajava alternativno, filogenetsko osnovano taksonomijo nedavno opisanega Chaetoniphargus lubuskensis Karaman \& Sket (Crustacea: Amphipoda: Niphargidae). Pravkar opisan nov rod in vrsta iz Dinarskega krasa je bila taksonomsko ovrednotena samo s klasičnim pristopom in na osnovi morfologije. Vrste rodov Niphargobatoides, Niphargobates, Chaetoniphargus, se razlikujejo od Niphargus spp. predvsem po malce zvišanem številu trnov na maksili I, po postopni redukciji maksilarnih in mandibularnih palpov, po močni redukciji urosomalnih struktur. Po molekulski analizi se izkaže, da so vgnezdeni v rod Niphargus in to ločeno. Če jih taksonomsko ločimo iz rodu Niphargus, ga naredijo parafiletskega. Ker pa jih je tako malo, s tem nič ne zmanjšamo moteče raznolikosti rodu. Molekulska filogenetska analiza bi vgnezdila vse tukaj omenjene vrste kot pripadnice rodu Niphargus, torej rodovna imena kot sinonima imena Niphargus. Postopno spreminjanje v morfologiji omenjenih nifargidov nam pokaže gladek prehod med družino Niphargidae in le malo sorodno družino Metacrangonyctidae. To je dodaten primer konvergence, ki kaže nujnost molekulskega preverjanja, ko ugotavljamo filogenetske odnose znotraj skupine Amphipoda

Ključne besede: podzemeljsko, taksonomija, filogenija, Amphipoda, Niphargidae, Metacrangonyctidae, Chaetoniphargus.

\footnotetext{
${ }^{1}$ Univerza v Ljubljani, Biotehniška fakulteta, Oddelek za biologijo, Ljubljana, E-mail: Boris.Sket@bf.uni-lj.si

${ }^{2}$ Montenegrin Academy of Sciences and Arts, Podgorica, E-mail: karaman@t-com.me
} 


\section{INTRODUCTION}

Recently (Karaman \& Sket 2018), the family Niphargidae (Crustacea: Amphipoda), has been enriched for an aberrant species within an independent genus. It was a negligible addition to the species number, but an important enrichment of the genera diversity. The family includes more than 400 species (HorTon et al., 2018), but the big majority of them belong to the diverse genus Niphargus. The related 12 genera are mainly monospecific and all together contain ca 20 species. Most of them are characterized by peculiarities in mouth parts, the organ very homogeneous in the otherwise diverse Niphargus. The unity of the mouth apparatus, contrasting to general and even diversity of other body parts, was what probably misled taxonomists into conviction that mouth parts are a phylogenetically stable and taxonomically particularly informative group of characters. For those few niphargids with deviation from normal (stygius type) niphargid type, foundation of independent genera has been a norm since ever. Illustrative is the ancient Niphargopsis Chevreux, 1922, founded for a species with multiplied setae and spines in mandibula and maxilla I. Chaetoniphargus (KARAMAN \& SKet 2018) is a member of a small group of small species; also related genera Niphargobates (Sket 1981), Niphargobatoides (KARAMAN 2016) and conditionally Niphargopsis (SCHELLENBERG 1942) are monospecific. Morphologically, these genera, accompanied even with Metacrangonyx and Longipodacrangonyx (Boutin 1994; Boutin \& MessoULI 1988), form a morphologically homogeneous group of taxa, characterized by a progressive reduction of head- and urosomal appendages and telson. However, a molecular analysis and biogeography demolish this impression.

The recently described Chaetoniphargus lubuskensis differs from other known genera of the family $\mathrm{Ni}$ phargidae by strongly reduced mandibular palpus consisting of only one small article, while all other known niphargids are provided with well developed 3-articulated mandibular palpus.

Considering this, we created the new genus Chaetoniphargus, with well defined morphological character states. It resembles the previously described genera Niphargobates, Niphargobatoides, as well as genera Metacrangonyx and Longipodacrangonyx. In some characters, some other small niphargids resemble this group, but they differ clearly in the 'normal' shape of the telson (Microniphargus, Niphargellus, Carinurella; Schellenberg 1934, 1938, 1942; Sket 1971). Molecularly, they are also alien to the group. We wanted to include an alternative, phylogenetically based taxonomy with the genus description, but the editor explicitly asked to abandon such a heading. With this article we are trying to correct the insufficiency.

\section{MATERIAL AND METHODS}

Morphology of Chaetoniphargus lubuskensis was taken from the description by Karaman \& SKeT (2018). Some specimens were preserved in ethanol $96 \%$ and analyzed molecularly in another study (MošKRIč,
2016). The Moškrič' OTU 'Niphargobates sp. NC144' is taxonomically identical with Chaetoniphargus lubuskensis.

\section{RESULTS}

The morphology of the great majority of Niphargidae species, including N. stygius (Schiödte) is a continuum of states in many characters, including also very characteristic mouthparts and uropods. However, in majority of them the shape and structure of mouthparts is only slightly affected. Very seldom (in Haploginglymus, Mateus \& Mateus 1958), the uropod III exopodite is unarticulated, but then with a long proximal article.
The following are the plesiomorphic character states of all larger (longer than $10 \mathrm{~mm}$ ) and of the great majority of smaller (down to $2 \mathrm{~mm}$ ) species of Niphargus. In only few small species, the mouth parts are apomorphic, modified, as mentioned below. Among them is the newly described niphargid C. lubuskensis. 
Table 1: Character states in morphology of oral and urosomal body parts in Niphargidae.

\begin{tabular}{|c|c|c|}
\hline 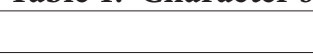 & plesiomorphy & apomorphy \\
\hline mandibula & $\begin{array}{l}\text { normally developed, with } 3 \text {-articulated } \\
\text { palpus, with richly setiferous article } 3\end{array}$ & $\begin{array}{l}\text { spines in the row between the mandibular } \\
\text { molar and incisor multiplied and differen- } \\
\text { tiated }\end{array}$ \\
\hline mandibular palpus & $\begin{array}{l}\text { palpus 3-articulated, with elongated arti- } \\
\text { cles }\end{array}$ & $\begin{array}{l}\text { palpus shortened, apically reduced, to } \\
\text { rudimentary }\end{array}$ \\
\hline maxilla I outer plate & $\begin{array}{l}\text { bearing very regularly } 7 \text { (exceptionally till } \\
\text { 15) stout, simple or bifid to pectinate } \\
\text { spines }\end{array}$ & $\begin{array}{l}\text { ca } 20 \text { spines; } \\
\text { spines multiplied and differentiated; }\end{array}$ \\
\hline maxilla I palpus & $\begin{array}{l}\text { overreaching the top of the outer plate; } \\
\text { biarticulate }\end{array}$ & shortened and uniarticulate \\
\hline \multirow[t]{2}{*}{ uropod 3} & longer than urosomites II+III & shorter than urosomite III \\
\hline & its endopodite biarticulate & endopodite uniarticulate \\
\hline \multirow[t]{2}{*}{ telson } & $\begin{array}{l}\text { as long or longer than wide, deeply (more } \\
\text { than } 1 / 2 \text { ) cleft }\end{array}$ & $\begin{array}{l}\text { with broadly rounded apices; less deeply } \\
\text { cleft }\end{array}$ \\
\hline & with more than 1 spine on each lobe & spines replaced by setae \\
\hline
\end{tabular}

The genera Niphargobates and Niphargobatoides are morphologically well defined, so is also Chaetoniphargus. They apparently form a phyletic group with some changes of oral appendages in progress. In process is the multiplying of mandibular and maxillary setae and the reduction of some appendage parts (e.g. palpus), beside this also reduction of uropods III. Telson is losing its niphargid character; its clipping is getting shallower, apices less prominent and less setose.

We based our recognition of different genera based on traditionally used morphological characters, supposedly important differences, which allowed to classify (divide) the family Niphargidae into 13 genera. They have been mainly applied already by BARNARD \& BARNARD (1983).

Within the family Niphargidae, genus Chaetoniphargus differs from the genus Niphargus by strongly reduced mandibular palpus and only indistinctly triturative molar, by strongly reduced palpus of maxilla I, by uniarticulate accessory flagellum of antenna I, by short and partially reduced uropod III with uniarticulate exopodite.
Within other genera, Chaetoniphargus is morphologically most similar (KARAMAN \& SKET 2018) to Niphargobates and Niphargobatoides. They resemble in the general body-shape, maxilla I, maxilliped, telson, uropod III, but Niphargobatoides lefkodemonaki (Sket) is still provided with a well developed 3-articulate mandibular palpus, maxilla II inner plate is larger than the outer one, its antenna I accessory flagellum is 2 -articulated, uropod III with 2 -articulated exopodite, telson is Niphargus-like, dactylus of gnathopods with several setae along outer margin. Niphargobates orophobata resembles Chaetoniphargus (in telson, maxilliped, accessory flagellum, maxilla I, uropod III), but differs remarkably by the mandible, by maxilla II with outer plate smaller than inner one.

Other genera of the family Niphargidae differ much more from the genus Chaetoniphargus. It is very interesting that within the family Niphargidae, most taxa (over 400) have similarly shaped mouthparts, despite the fact that they are living in very various habitats (interstitial waters, subterranean streams and lakes, springs) and that they are differently sized (from 2 to $30 \mathrm{~mm}$ ).

\section{DISCUSSION}

Taxa, which are so convincingly grouped by morphological characters, cannot be grouped by molecular means.

A molecular phylogenetic analysis done recently by MošKrič (2016) shows that most OTUs mentioned in the identification key of Karaman \& SKet (2018) are phylogenetically nested within the genus Niphargus. The taxonomic emancipation (= generic independence) of any one species renders the genus Niphargus paraphyletic. Although the paraphyly is necessarily acceptable in gammarid systematics (Hou \& SKeт 2016), it brings no practical benefits in this special case. Only 
few of so erected genera include more than one species. Thus, they do not make the Niphargidae system significantly simpler.

More specifically, not only Niphargobates as one of the morphologically most aberrant niphargid genera, but also the recently described Chaetoniphargus, named by MošKrič (2016) as 'Niphargobates sp. (NC144)', appeared to be nested within Niphargus (MošKrič 2016). It is also important to tell that both morphologically similar taxa are remarkably different by their phylogenetic origin. Niphargobates orophobata Sket is the basally split off taxon of the one group of 'giant' species (sensu Delić et al. 2017), containing Niphargus steueri Schellenberg, N. arbiter G. Karaman, N. hebereri Schellenberg. The "Niphargobates sp. (NC144)" (here described as Chaetoniphargus lubuskensis) is the closest (but still very distant) sister to another 'giant', Niphargus orcinus Joseph. Thus, the molecular analysis supports neither the genus Niphargobates nor a new genus Chaetoniphargus. The generic emancipation of any of them makes the rest of Niphargus paraphyletic, without a compensating benefit. While the fusion of both species, which are morphologically very similar, into one genus, would result even in a polyphyletic entity. The Central European species Niphargopsis casparyi (Pratz) is again from another molecular niphargid environment (Delić et al. 2017; MošKRIČ 2016); this is a species with even more spines in maxilla I, but otherwise not similar to here mentioned niphargids.

Thus, the reduction and transformation of oral appendages is a homoplasy, convergence. It is not in a functional connection with their smallness, since equally small or smaller species are not necessarily similar. The small size of all here treated species is in discrepancy with the fact, that the majority of small and the very smallest Niphargus spp. exhibit normally built mouth parts as well as normal appendages of the urosomite III. Among the largest niphargids are the exceedingly stout orcinus-type and the prominently elongated krameri-type species, both reaching about $30 \mathrm{~mm}$ length. The smallest niphargid species are below $5 \mathrm{~mm}$ long, some close to $2 \mathrm{~mm}$, like $N$. longidactylus Ruffo $(5 \mathrm{~mm}), N$. transitivus Sket $(2 \mathrm{~mm}), N$. pupetta (Sket) (2 mm) (SKeT 1971), but we know nothing about their way of feeding and functioning of the mouth parts. The functioning of this type of mouth parts is sometimes characterized as "filtratory", but it has in fact never been observed working.

Besides being mutually convergent, genera Niphargus, Niphargobates, Chaetoniphargus, represent another case of an extreme homoplasy. The supposedly unrelated amphipods, Metacrangonyx spp. and Longipodacrangonyx maroccanus (Boutin \& Messouli, 2-3 mm) are similar (Sket, Krapp-Schickel 2016) to the here treated niphargids exceedingly in some details of the head and urosomal appendages, to some degree also in the general habitus.

The animal's habitus (except that the body is laterally depressed) and size is the same as of those niphargids; mandibular palpus is uniarticulate and vestigial, maxilla I is normally developed, but with modestly elevated spines' number (in relation to typical Niphargus spp.), uropod III not longer than urosomite III, its exopodite uniarticulate and remarkably shorter than peduncle, endopodite vestigial; telson is semicircular, not notched at all to slightly terminally concave and without stronger spines. A difference in relation to the above treated niphargid group is the shape of gnathopod propodi and the normally 3-5 articulated accessory flagellum. In these two characters, metacrangonyctids deviate from here treated niphargids; the rest would support their belonging to Niphargidae. Considering the telson shape in Chaetoniphargus lubuskensis and Metacrangonyx ilvanus (Sтосн 1997) it could be easy to imagine that the entire (non-chipped) telson of most metacrangonyctids is only the ultimate state of its transformation. The accessory flagellum of antenna I is normally 3-5 articulate in metacrangonyctids and normally biarticulate (or even uniarticulate), but never more, in niphargids.

The third, the strongest, distinguishing group of characters are in maxilla I. In both, the spines of the outer lobe are more numerous than in 'normal' Niphargus spp. The palpus was subjected to slight reduction, never occurring in ordinary niphargids. In metacrangonyctids, this extremity is stable in structure, and different from Niphargus. The biarticulate palpus in metacrangonyctids is bearing terminally some stout spines and some short setae. The inner lobe is provided with a row of pinnate marginal setae. Neither of these characters is present in any Niphargus sp.

This case makes us easy to imagine a generation of convergent, morphologically nearly equal, unrelated amphipod species. To support their unrelatedness, both families are geographically very distant and different. Niphargus inhabits the virtually whole Europe and Near East, from Ireland to Iran. Its area includes some Mediterranean islands. The species of the here treated type are limited to SE Europe (Dinarides and Greece, Niphargopsis the Central Europe). Metacrangonyctids occur in a wide belt along the southern shores of Mediterranean between the Israel and Islas Canarias. The only area where these groups are sympatric, are some Mediterranean islands (e.g. Elba, Sтосн 1997; Ruffo \& Sтосн 2005). Niphargus spp. have never been found in Africa while metacrangonyctids never in Europe. 


\section{CONCLUSIONS}

These facts demonstrate the high possibility of the homoplastic past of seemingly related amphipod species which means also possibility of mistakes in morphologically based taxonomy of Amphipoda. Although the taxonomy of Niphargidae is not yet simply solved, considering data of MošKr IČ (2016), Niphargobatoides, Niphargobates, Chaetoniphargus and Niphargopsis are synonymous with Niphargus. These data also dispossess legitimacy to phylogenetic (and taxonomic) studies taken without any molecular verification.

\section{POVZETEK}

Nedavno opisana jamska postranica Chaetoniphargus lubuskensis Karaman \& Sket (Crustacea: Amphipoda: Niphargidae) z Velebita je bila sistematsko uvrščena na osnovi morfoloških znakov in po klasičnem postopku. Tukaj podajava filogenetsko študijo na osnovi molekulske filogenetske analize. Rod Niphargus vključuje približno 400 vrst, v 12 sorodnih rodov pa uvrščamo še okoli 20 vrst. Skupina rodov Niphargobatoides, Niphargobates in Chaetoniphargus so podobne živali, od Niphargus jih ločuje predvsem postopna redukcija obustnih okončin in zadka.

Poprejšnja molekulska analiza kaže, da morfološka podobnost teh rodov ne odseva sorodstvenih, filogenetskih vezi. Vsi rodovi so sicer vgnezdeni v rodu Niphargus, vendar ločeno, so torej plod konvergenčne evolucije. Medtem, ko ima vseh 400 vrst nifargov sklop obustnih okončin oblikovan po tipu tipske vste Niphar- gus stygius, pa imajo omenjeni trije rodovi konvergenčno preoblikovanega, različno reduciranega. Podobno je s telzonom in uropodi III. A homoplazija je šla še dlje. Ti trije nifargobatski rodovi so se morfološko močno približali sistematsko-filogenetsko dokaj oddaljeni družini Metacrangonyctidae. Mandibula je postala pri obeh družinah zaradi pokrnitve palpa skoraj enaka, uropod III se je razvil podobno konvergentno, pa je maxila I pri vseh vrstah metakrangoniktidov skoraj enaka, družinsko značilna. Telzon predstavlja navidezno gladko filetsko vrsto Niphargus+Niphargobatoides - Niphargobates - Chaetoniphargus - Metacrangonyx ilvanus - druge Metcarangonyx spp.

Tukaj imamo opravka še z enim primerom konvergence, ki kaže nujnost molekulskega preverjanja pri sistematskih študijah na postranicah (Crustacea: Amphipoda).

\section{REFERENCES - LITERATURA}

Barnard, J.L \& Barnard, C.M., 1983: Freshwater amphipods of the World. I. Evolutionary patterns. II. Handbook and bibliography.- Hayfield Associates: Mt. Vernon, Virginia, 1983, pp. XIX +849 pages, 50 figs., 7 graphs, 98 maps, 12 tables.

Boutin, C., 1994: Phylogeny and biogeography of metacrangonyctid amphipods in North Africa Hydrobiologia 287 (1): 49-64.

Boutin, C. \& Messouli, M., 1988: Longipodacrangonyx maroccanus, n. gen., n. sp., Nouveau Representant du groupe Metacrangonyx dans les eaux souterraines du Maroc Crustaceana. Supplement, No. 13, Studies on Amphipoda (Proceedings of the VIth International Colloquium on Amphipod Crustaceans, Ambleteuse, France, 28 June-3 July 1985) pp. 256-271.

Chevreux, E., 1922: Sur un nouveau genre d'amphipodes de la faune francaise. Bulletin du Muséum National d'Histoire Naturelle, Paris, 7: 487-488.

Delić, T., Švara, V., Coleman, C. O., Trontelj, P., Fišer, C., 2017: The giant cryptic amphipod species of the subterranean genus Niphargus (Crustacea, Amphipoda). Zoologica scripta, 2017, pp. 1-13.

Horton, T., lowry, J., De Broyer, C., Bellan-Santini, D., Coleman, O., Daneliya. M., Dauvin, J.-C., Fišer, C., Gasca, R., Grabowski, M., Fuerra-Garcia, J. M., Hendrycks, E., Holsinger, J., Hughes, L., Jauma, D., Jazdzewski, K., Just, J., Kamaltynov, R. M., Kim, Y.-H., King, R., Krapp-Schickel, T., Lecroy, S., Lörz, A.-N., Senna, A.R., Serejo, C., Sket, B., Tanberg, A. H., Thomas, J., Thurston, M., Vader, W., Väonölö, R. R, Vonk, R., White, K., Zeidler, W., 2018: World Amphipoda Database; Niphargus Schiödte, 1849: World Register of Marine Species. 
Hou, Z. \& Sket, B., 2016: A review of Gammaridae (Crustacea: Amphipoda): the family extent, its evolutionary history, and taxonomic redefinition of genera. Zoological Journal of the Linnean Society, 176 (2): 323-348, https:// doi.org/10.1111/zoj.12318

Karaman, G., 2016: Two new genera of the family Niphargidae from Greece (Contribution to the Knowledge of the Amphipoda 287). Agriculture \& Forestry, Podgorica, 62 (1): 7-27.

Karaman, G. \& Sket, B., 2018: A new genus and species of Niphargidae from Velebit, Croatia. Zootaxa (in print)

Mateus, A. \& Mateus, E., 1958: Un nouveau genre et une nouvelle espece d Amphipode troglobie du Portugal. Publicaçoes do Instituto de Zoologia "Dr. Augusto Nobre", Faculdade de Ciencias do Porto, Coimbra, 59: 1-15.

Moškrič, A., 2016: Postavitev filogenetskega ogrodja rodu slepih postranic Niphargus (Crustacea: Amphipoda) na podlagi molekulskih metod: doktorska disertacija (The formation of a phylogenetic framework for the genus Niphargus (Crustacea: Amphipoda) using molecular methods). Univerza v Ljubljani, Biotehniška fakulteta, Disertacija.

Ruffo, S., Sтосн, F. (eds.), 2005: Checklist e distribuzione della fauna italiana. Ministero dell' ambiente e della tutella del' territorio.

Schellenberg, A., 1934: Eine neue Amphipoden-Gattung aus einer belgischen Höhle nebst Bemerkungen über die Gattung Crangonyx. Zoologischer Anzeiger, 106 (9): 215-218.

Schellenberg, A., 1938:. Niphargellus, eine neue subterrane Amphipodengattung an der Ost- und Westgrenze des Reiches. Zoologischer Anzeiger, 122 (9-10): 245-248.

Schellenberg, A., 1942: Flohkrebse oder Amphipoda. In: Die Tierwelt Deutschlands und der angrenzenden Meeresteile. Jena: Fischer

Sкет, B., 1971: Vier neue aberrante Niphargus-Arten (Amphipoda, Gammaridae) und einige Bemerkungen zur Taxonomie der Niphargus-ähnlichen Gruppen. Razprave, Slovenska Akademija Znanosti in Umetnosti, Ljubljana, 14 (1): 1-25.

SкEт, B., 1981: Niphargobates orophobata n. g., n. sp. (Amphipoda, Gammaridae, s. l.) from cave waters in Slovenia (NW Yugoslavia). Biološki vestnik, Ljubljana, 29 (1): 105-118.

Sket, B., 1990: Is Niphargobates lefkodemonaki sp. n. (Crustacea: Amphipoda) from Kriti (Greece) a Zoogeographical Enigma? Zoologische Jahrbücher, Abteilung für Systematik, 117: 1-10.

Sket, B. (Krapp-Schickel, T.), 2016: Interview with Boris Sket. Amphipod newsletter, 40: 2-10.

Sтосн, F., 1997: Metacrangonyx ilvanus $n$. sp., the first Italian representative of the family Metacrangonyctidae (Crustacea: Amphipoda). Annales limnologie, 33 (4) 1997: 255-262. 


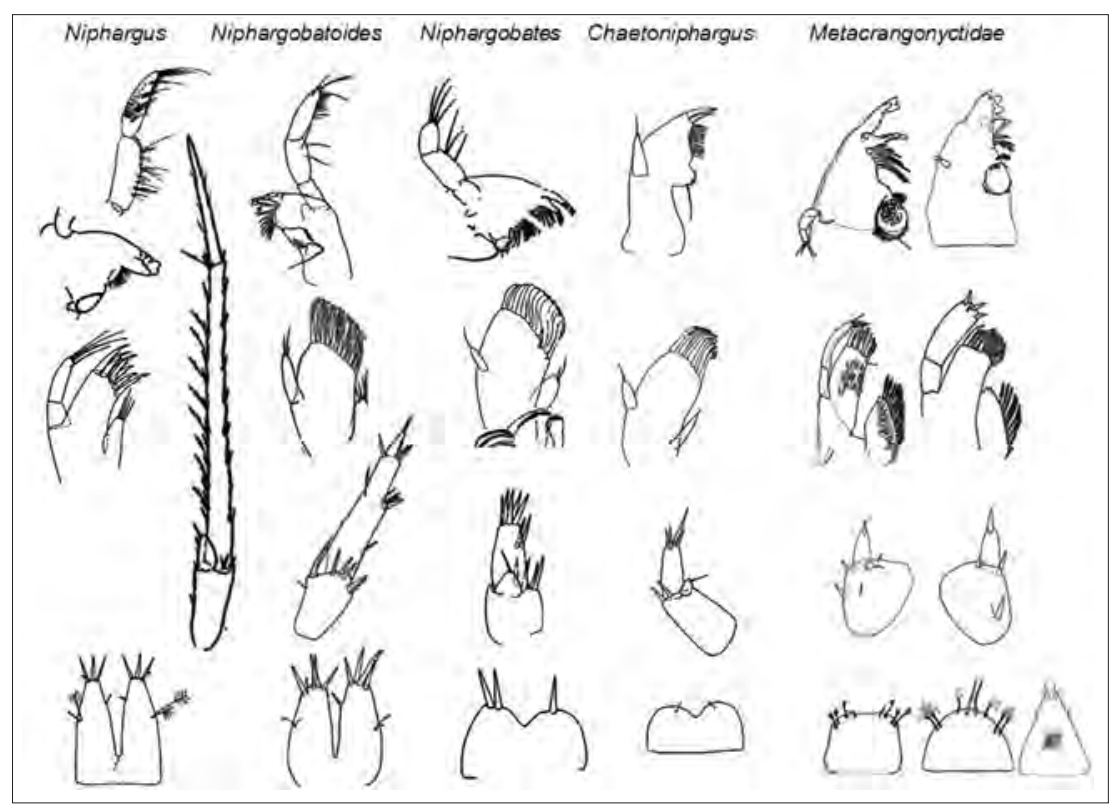

Figure 1, Some taxonomically relevant body parts of Niphargidae and Metacrangonyctidae. In columns follow: genus (or family) name // mandibula // maxilla I // uropod III // telson. Drawings are not in scale. Taken from C. Boutin \& M. Messouli,G.

Karaman, B. Sket, F. Stoch.

Slika 1, Nekateri taksonomsko pomembni deli telesa pri družinah Niphargidae in Metacrangonyctidae. V stolpcih si sledijo: ime rodu (ali družine) // mandibula // maxilla I // uropod III // telson. Risbe niso v merilu. Povzeto po C. Boutin \& M. Messouli, G. Karaman, B. Sket, F. Stoch 